\title{
High yield of mannosylglycerate production by upshock fermentation and bacterial milking of trehalose-deficient mutant Thermus thermophilus RQ-1
}

\author{
K. Egorova • T. Grudieva • C. Morinez • J. Kube • \\ H. Santos • M. S. da Costa • G. Antranikian
}

Received: 10 August 2006 /Revised: 27 February 2007 / Accepted: 27 February 2007 / Published online: 5 March 2007

(C) Springer-Verlag 2007

\begin{abstract}
A production process, using upshock fermentation and osmotic downshock, for the effective production/ excretion of mannosylglycerate (MG) by the trehalosedeficient mutant of the strain Thermus thermophilus RQ-1 has been developed. In the first phase of fed-batch fermentation, the knockout mutant was grown at $70^{\circ} \mathrm{C}$ on a $\mathrm{NaCl}$-free medium. After the culture reached the end of the exponential growth phase, upshift in temperature and $\mathrm{NaCl}$ concentration was applied. The temperature was increased to $77^{\circ} \mathrm{C}$, and $\mathrm{NaCl}$ was added up to $3.0 \%$ and kept constant during the second phase of fermentation. Although this shift in cultivation parameters caused a dramatic drop of cell density, a significant improvement in accumulation of MG up to $0.64 \mu \mathrm{mol} / \mathrm{mg}$ protein compared to batch fermentations $(0.31 \mu \mathrm{mol} / \mathrm{mg}$ protein) was achieved. A total yield of $4.6 \mathrm{~g}$ $\mathrm{MG} / \mathrm{l}$ of fermentation broth was obtained in the dialysis
\end{abstract}

\footnotetext{
K. Egorova · T. Grudieva • C. Morinez • G. Antranikian $(\bowtie)$ Institute of Technical Microbiology,

Hamburg University of Technology,

Kasernenstr 12, 21073 Hamburg, Germany

e-mail: antranikian@tuhh.de

J. Kube

Institute of Bioprocess and Biosystem Engineering,

Hamburg University of Technology,

Denickestr. 15, 21073 Hamburg, Germany

H. Santos

Instituto de Tecnologia Química e Biológica,

Universidade Nova de Lisboa,

Rua da Quinta Grande, 6, Apartado 127,

2780-156 Oeiras, Portugal

M. S. da Costa

Laboratorio de Microbiologia, Departamento de Zoologia,

Universidade de Coimbra,

3004-517 Coimbra, Portugal
}

bioreactor with a productivity of $0.29 \mathrm{~g} \mathrm{MG}^{-1} \mathrm{~h}^{-1}$. The solute was released from the harvested biomass by osmotic downshock using demineralized water at $70^{\circ} \mathrm{C}$. More than $90 \%$ of the intracellularly accumulated solute was recovered from the water fraction. The process was very efficient, as hyperosmotic shock, release of the solute, and reiterative fed-batch fermentation could be repeated at least four times.

Keywords Mannosylglycerate $\cdot$ Fermentation $\cdot$ Thermus

\section{Introduction}

Many halotolerant or halophilic microorganisms accumulate low-molecular-weight organic compounds in response to osmotic stress. These compounds, so-called compatible solutes, do not interfere with cell metabolism. Some solutes, like trehalose, $\alpha$-glutamate, glycine betaine, or proline are frequently found in nonthermophilic organisms; others, like di-myo-inositol phosphate or diglycerol phosphate are restricted to (hyper)thermophiles; some compounds, like mannosylglycerate $(\mathrm{MG})$, are strongly associated with (hyper)thermophiles, appearing rarely in mesophiles (da Costa et al. 1998). Although MG was initially identified in red algae of the order Ceramiales (Bouveng et al. 1955), it is one of the most widespread solutes in (hyper)thermophiles. MG was first found in the thermophilic bacteria Thermus thermophilus and Rhodothermus marinus (Nunes et al. 1995; Silva et al. 1999). Since then, it has been reported to occur in many hyperthermophilic archaea: the crenarchaeotes Aeropyrum pernix and Stetteria hydrogenophila, the euryarchaeotes Archaeoglobus veneficus, Archaeoglobus profundus, Methanothermus fervidus, and also some genera of the order Thermococcales (Martins and Santos 1995; Martins et al. 1997; Lamosa et al. 1998; Gonçalves et al. 
2003; Neves et al. 2005; Empadinhas and da Costa 2006). The level of MG increases primarily in response to osmotic stress, the only known exception to this behavior being found in $R$. marinus where it is the major solute at supraoptimal growth temperatures. The strong correlation between MG and (hyper)thermophiles led to the hypothesis that this solute would be specially suited to protect cellular components, namely, proteins, against heat damage. Indeed, in vitro assays with different proteins have confirmed the remarkable ability of MG to improve protein stability (Faria et al. 2004), and as a result, several patents on the applicationof MG as stabilizer of biomaterials have been filed (Lentzen and Schwarz 2006).In practice, however, the use of MG in biotechnological applications is hampered by the current high production cost; therefore, the development of processes leading to high product yields is mandatory.

Because of the limitations of chemical synthesis, development of microbial system suitable for the industrial production of MG is of great interest. However, expression of sufficient quantities of the intracellular solute by recombinant thermophiles still represents a bottleneck for the industrial applications (Sonnleitner 1983; Krahe et al. 1996). The development of fermentation technology represents a major step towards high product yield and stable production process. The removal of growth-inhibiting metabolites from the cell suspension using dialysis membranes can further increase the efficiency of microbial processes. As a producing strain, one of prospective and well-studied MG-producers $T$. thermophilus RQ-1 was chosen, where the genes for the synthesis of trehalose, the main compatible solute in $T$. thermophilus, were knocked out (Silva et al. 2003).

In this paper, the production of MG by trehalosedeficient $T$. thermophilus RQ-1 in fed-batch fermentation was established. Because the production of MG increases significantly at high $\mathrm{NaCl}$ concentrations and/or high temperatures, both of which strongly inhibit growth of the strain, upshock fermentation strategy was used to increase the effective yield of the solute. Hypoosmotic shock was successfully applied to release the solute from the cells, which enables rapid purification of the desired product.

\section{Materials and methods}

Microorganism and growth conditions

The trehalose-deficient strain T. thermophilus RQ-1 (Silva et al. 2003) was grown on a complex medium of the following composition (per liter, $\mathrm{pH}$ 7.5): $100 \mathrm{ml}$ stock macronutrient solution, $5 \mathrm{ml}$ stock oligoelement solution, $0.05 \mathrm{mM}$ iron citrate, $3 \mathrm{mM} \mathrm{NaH} \mathrm{PO}_{4} \cdot 12 \mathrm{H}_{2} \mathrm{O}, 2 \mathrm{mM}$
$\mathrm{KH}_{2} \mathrm{PO}_{4}$, and $2 \mathrm{~g}$ tryptone. Stock macronutrient solution contained (per liter): $1,000 \mathrm{mg}$ nitrilotriacetic acid, $400 \mathrm{mg}$ $\mathrm{CaSO}_{4} \cdot 2 \mathrm{H}_{2} \mathrm{O}$, and $2,000 \mathrm{mg} \mathrm{MgCl} 2 \cdot 6 \mathrm{H}_{2} \mathrm{O}$. Stock oligoelement solution contained (per liter): $220 \mathrm{mg} \mathrm{MnSO}_{4} \cdot \mathrm{H}_{2} \mathrm{O}$,

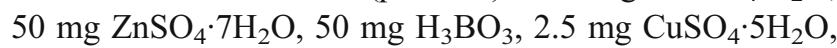
$2.5 \mathrm{mg} \mathrm{Na} 2 \mathrm{MoO}_{4} \cdot 2 \mathrm{H}_{2} \mathrm{O}$, and $4.6 \mathrm{mg} \mathrm{CoCl}{ }_{2} \cdot 6 \mathrm{H}_{2} \mathrm{O}$. Glucose $(4 \mathrm{~g} / \mathrm{l})$, tenfold concentrated vitamin solution $(10 \mathrm{ml} / \mathrm{l})$, and kanamycin $(30 \mathrm{mg} / \mathrm{l})$ were sterilized separately and added after autoclaving. Kanamycin was added to preserve the strain characteristics. The vitamin solution contained (per liter): $4 \mathrm{mg}$ thiamine, $4 \mathrm{mg}$ riboflavin, $4 \mathrm{mg}$ pyridoxine monohydrochloride, $4 \mathrm{mg}$ D-biotin, $4 \mathrm{mg}$ folic acid, $4 \mathrm{mg}$ myo-inositol, $4 \mathrm{mg}$ nicotinic acid, $4 \mathrm{mg}$ D-pantothenic acid, $4 \mathrm{mg} p$-aminobenzoic acid, and $4 \mathrm{mg}$ vitamin $\mathrm{B}_{12} . \mathrm{NaCl}$ was added to the medium before autoclaving to achieve final concentrations in the range $1-5 \%, w / v$. In fed-batch fermentations, a highly concentrated glucose solution $(636 \mathrm{~g} / \mathrm{l})$ was used as a feed stock.

\section{Fermentation}

All fermentations were carried out in a 2-1 Visual Safety Bioreactor (Bioengineering AG, Wald, Switzerland) with a working volume of 1.51 . Temperature and $\mathrm{pH}$ in the bioreactor were controlled automatically. A pH electrode was used to control $\mathrm{pH}$ at 7.5 with the addition of either $2 \mathrm{M} \mathrm{NaOH}$ or $10 \% \mathrm{H}_{3} \mathrm{PO}_{4}$. Aeration was kept at $0.3 \mathrm{vvm}$ and the dissolved oxygen concentration was measured using a $\mathrm{pO}_{2}$ electrode. To maintain a constant oxygen partial pressure above $40 \%$, the stirrer speed was set between 1,000 and 1,500 rpm, and the exhaust gas cooled to minimize evaporation losses. Pressure in the bioreactor was atmospheric. In fed-batch experiments, the glucose concentration in the bioreactor was regulated to $4 \mathrm{~g} / \mathrm{l}$, using the glucose-feed stock solution (636 g/l).

The dialysis bioreactor, manufactured by Bioengineering (Switzerland), consists of two cylindrical reactors that are set into one another. The inner chamber, formed by the inner cylindrical reactor, is separated from the outer chamber by a dialysis membrane of $30 \mathrm{kDa}$ cutoff (Poertner and Maerkl 1998; Fuchs et al. 2002). Fresh medium (dialysate) was prepared and sterilized in a 20-1 bottle. The temperature of the dialysate was controlled at $70^{\circ} \mathrm{C}$. The dialysate pumping was started at an optical density at $600 \mathrm{~nm}\left(\mathrm{OD}_{600}\right)$ of 3.0 at the rate of $2 \mathrm{l} / \mathrm{h}$. Bioreactors were inoculated with exponentially growing preculture.

\section{Osmotic shocks}

In fed-batch experiments, upshock was performed once the culture reached the early stationary growth phase by adding the concentrated salt solution to a final concentration of $2-4 \% \mathrm{NaCl}$ and/or increasing the temperature to $77^{\circ} \mathrm{C}$. 
For osmotic downshock, the principle of "bacterial milking" process was used according to the physiological features of the strain (Sauer and Galinski 1998). After $1 \mathrm{~h}$ of hyperosmotic shock, the biomass was collected by centrifugation for $20 \mathrm{~min}$ at 4,000 rpm and resuspended in equal volume of hot $\left(70^{\circ} \mathrm{C}\right)$ demineralized water to induce the rapid release of solute. The suspension was incubated at $70^{\circ} \mathrm{C}$ for $1 \mathrm{~h}$, and cells were separated by centrifugation at the same conditions, resuspended in the original volume of fresh medium, and returned into the bioreactor to enable growth of the cells and further synthesis of MG.

\section{Analytical methods}

Microbial growth was monitored spectrophotometrically (Genesys 10vis) by measuring the OD of diluted samples in triplicate at $600 \mathrm{~nm}$. Cell protein content was determined by the Bradford assay (Bradford 1976) after cell ultrasonication and subsequent lysis in $0.1 \mathrm{M} \mathrm{NaOH}$ overnight at $37^{\circ} \mathrm{C}$. Bovine serum albumin was used as the protein standard.

Glucose was measured offline in clear culture supernatant using a glucose analyzer, YSI 2700 select (Yellow Springs Instruments, USA) according to instructions of the manufacturer. Alternatively, glucose-measuring stripes Combur $^{3}$ Test (Roche Diagnostics) were used for frequent glucose estimation.

\section{Organic solute extraction}

MG was extracted from the cell pellet twice after boiling with $80 \%$ ethanol as described previously (Reed et al. 1992). Ethanol was removed from the collected supernatants by evaporation, and the residue was freeze-dried. Water samples $(3 \times 50 \mathrm{ml}$ each) containing $\mathrm{MG}$ (obtained after hypoosmotic downshock) were lyophilized. The complete removal of lipids from all the samples was achieved by extraction with a mixture of water-chloroform $(2: 1, \mathrm{v} / \mathrm{v})$. After centrifugation at $13,000 \mathrm{rpm}$ for $10 \mathrm{~min}$, the aqueous phase was analyzed by high-performance liquid chromatography (HPLC).

\section{HPLC analysis}

The samples were filtered through a $0.2-\mu \mathrm{m}$ pore size filter (Pall GHP-Membrane Acrodisc 13-mm syringe filter) and analyzed using reversed phase Aminex HPX-87 H column (300 by $7.8 \mathrm{~mm}$ ) with a particle size of $9 \mu \mathrm{m}$ (Bio-Rad Laboratories) and a refractive index detector (Merck La Chrom L-7490). The injected sample $(10 \mu \mathrm{l})$ was eluted at $50^{\circ} \mathrm{C}$ using $\mathrm{H}_{2} \mathrm{SO}_{4}(0.15 \mathrm{M})$ as the mobile phase with a flow rate of $0.6 \mathrm{ml} / \mathrm{min}$. For the determination of the quantity of $\mathrm{MG}$ in the samples, standards of 1,5 , and
$10 \mathrm{mM}$ MG were analyzed. MG concentration was determined as the amount of $\mathrm{MG}(\mu \mathrm{mol})$ extracted from the cells (mg protein). Space time yield coefficient is defined as amount of MG (g) produced in 11 medium per hour. Yield is defined as the amount of $\mathrm{MG}(\mathrm{g})$ produced in 11 medium.

\section{Nuclear magnetic resonance spectroscopy}

Freeze-dried extracts were dissolved in $\mathrm{D}_{2} \mathrm{O}$ and analyzed by nuclear magnetic resonance (NMR). NMR spectra were acquired in a Bruker AMX300 spectrometer using a 5-mm inverse detection probe head at $25^{\circ} \mathrm{C}$, with presaturation of the water signal, $60^{\circ}$ flip angle, and a repetition delay of 60 s. A known amount of sodium formate was added and used as a concentration standard.

\section{Results and discussion}

Effect of temperature and salinity on $\mathrm{MG}$ production

The influence of salinity and/or temperature on the growth and MG production of the trehalose-deficient mutant $T$. thermophilus RQ-1 was investigated in batch and fed-batch fermentations. The trehalose-deficient mutant $T$. thermophilus RQ-1 showed a growth behavior, which is typical of halotolerant microorganisms with optimal growth in the medium without $\mathrm{NaCl}$. The highest growth rates $(0.26-$ $0.32 \mathrm{~h}^{-1}$ ) were observed when the strain was grown in a medium lacking $\mathrm{NaCl}$ in batch as well as in fed-batch fermentation, reaching a final OD of 4.6-5.0. However, under these conditions, only traces of $\mathrm{MG}$ were detected in the cells. Similar to the results reported previously for wildtype Thermus strains (Nunes et al. 1995), the trehalosedeficient strain demonstrated a linear decrease in the growth rate as a function of the salt concentration. In batch fermentations, the increase in the $\mathrm{NaCl}$ start concentration up to $3.0 \%(\mathrm{w} / \mathrm{v})$ resulted in a decrease in the growth rate from 0.26 to $0.12 \mathrm{~h}^{-1}$ and a prolongation of the lag phase up to $72 \mathrm{~h}$, which is comparable to that of closely related Thermus strains (Sonnleitner et al. 1982; Nunes et al. 1995). This was paralleled with the production of MG up to $0.31 \mu \mathrm{mol} / \mathrm{mg}$ of protein after growth for $96 \mathrm{~h}$, reaching a final $\mathrm{OD}$ of 2.8. No growth was detected at start $\mathrm{NaCl}$ concentrations above $3.0 \%(\mathrm{w} / \mathrm{v})$.

The influence of temperature on growth of the strain was examined at two different $\mathrm{NaCl}$ concentrations ( 0 and $2 \%$ ). In the medium lacking $\mathrm{NaCl}$, the strain was able to grow up to a temperature of $80^{\circ} \mathrm{C}$.A significant decrease in the growth rate from 0.21 (growth at $70^{\circ} \mathrm{C}$ ) to $0.11 \mathrm{~h}^{-1}$ was observed when cultivation was performed at $75^{\circ} \mathrm{C}$. At $80^{\circ} \mathrm{C}$, the growth rate decreased to $0.09 \mathrm{~h}^{-1}$, and the lag phase was 


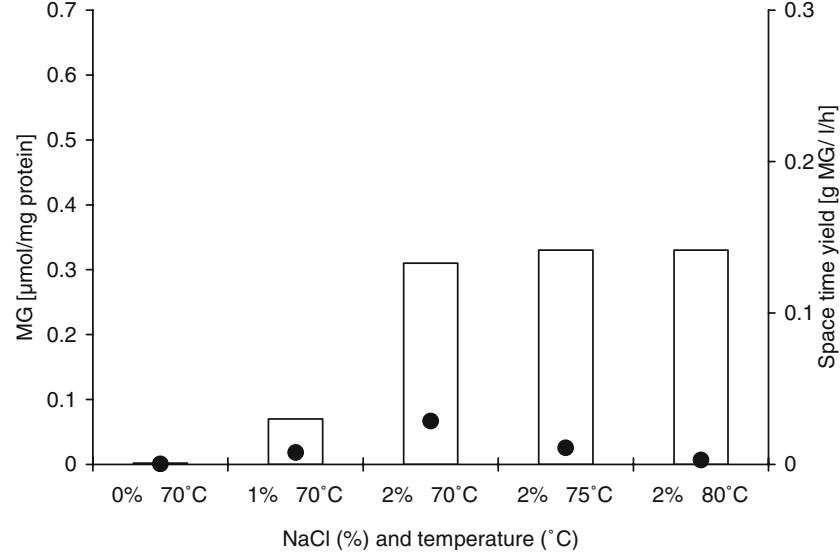

Fig. 1 Influence of salinity and temperature on accumulation and production of $\mathrm{MG}$ in a batch process with the trehalose-deficient mutant T. thermophilus RQ-1. Dots, production of MG (g MG $\left.\mathrm{l}^{-1} \mathrm{~h}^{-1}\right)$; columns, intracellular concentration of $\mathrm{MG}(\mu \mathrm{mol} \mathrm{MG} / \mathrm{mg}$ protein). Growth experiments were performed on the complex medium in a 2-1 bioreactor. The biomass was collected after the microbial growth reached stationery phase and analyzed by HPLC for MG

prolonged to $30 \mathrm{~h}$. A profound effect was observed when $\mathrm{NaCl}$ was added to the medium. At a salt concentration of $2.0 \%$, only a slight decrease in the growth rate $\left(0.18 \mathrm{~h}^{-1}\right)$ at $75^{\circ} \mathrm{C}$ was observed. This was paralleled with the synthesis of MG (Fig. 1). No significant increase in the level of MG accumulation was detected, when growth was performed at suboptimal temperatures. Thus, increasing the cultivation temperature to $75^{\circ} \mathrm{C}$ resulted in $9 \%$ increase in the $\mathrm{MG}$ content as compared to that at $70^{\circ} \mathrm{C}$.

The production of MG by the mutant T. thermophilus RQ-1 in the medium containing up to $3.0 \% \mathrm{NaCl}$ is much higher $(0.45 \mu \mathrm{mol} / \mathrm{mg}$ protein $)$ than the production reported for halophilic MG producers at the same salinities $(R$. marinus $[0.2 \mu \mathrm{mol} / \mathrm{mg}$ protein], Pyrococcus furiosus [0.06 $\mu \mathrm{mol} / \mathrm{mg}$ protein], and Palaeococcus ferrophilus
[0.28 $\mu \mathrm{mol} / \mathrm{mg}$ protein]; Martins and Santos 1995; Nunes et al. 1995; Neves et al. 2005). However, it has to be reported that the two other strains accumulate several compatible solutes: $R$. marinus produces also mannosylglyceramide $(0.5 \mu \mathrm{mol} / \mathrm{mg}$ protein $)$, trehalose, and glutamate and $P$. furiosus also produces di-myo-inositol-phosphate $(0.18 \mu \mathrm{mol} / \mathrm{mg}$ protein $)$.

\section{Upshock fermentation}

Because the production of $\mathrm{MG}$ increases significantly at high $\mathrm{NaCl}$ concentrations and/or high temperatures, both of which strongly inhibit growth of the microorganism, upshock fermentation strategy was used to increase the effective yield of the solute. Fermentation was performed in two phases. In the first phase of fermentation, the strain was grown at $70^{\circ} \mathrm{C}$ in a $\mathrm{NaCl}$-free medium using glucose feeding. After the microorganism reached the end of the exponential growth phase, a shift in temperature and $\mathrm{NaCl}$ concentration was applied. The concentrated $\mathrm{NaCl}$ solution was added to give a final value of up to $3.0 \%(\mathrm{w} / \mathrm{v})$. The analysis of growth and MG production after 1, 3, 5, and $7 \mathrm{~h}$ of the hyperosmotic shock clearly showed that more than $80 \%$ of the synthetic activity of the cells was achieved $1 \mathrm{~h}$ after the shock (Fig. 2). After incubation of the cells at those conditions resulted in the synthesis of more MG, but a dramatic drop of cell density occurred. This resulted in a $50 \%$ decrease in the MG yield from 0.112 to $0.055 \mathrm{~g} \mathrm{MG}$ $\mathrm{l}^{-1} \mathrm{~h}^{-1}$. To keep the production of MG at the highest level, the variation of upshock parameters was tested, analyzing the intracellular MG accumulation $1 \mathrm{~h}$ after the hyperosmotic shock. The influence of salinity and temperature was investigated separately as well as in combination. The temperature was increased to $77^{\circ} \mathrm{C}$ and/or $\mathrm{NaCl}$ was added up to $2.0-4.0 \%$ and kept constant during the second phase
Fig. 2 Production of $M G$ in a fed-batch fermentation with the trehalose-deficient mutant $T$. thermophilus RQ-1 using hyperosmotic shock. Line, microbial growth (OD $600 \mathrm{~nm}$ ); dots, production of MG (g MG $1^{-1} \mathrm{~h}^{-1}$ ), columns, intracellular concentration of MG ( $\mu \mathrm{mol}$ $\mathrm{MG} / \mathrm{mg}$ protein). The microorganism was grown on the $\mathrm{NaCl}$-free complex medium with glucose feeding $(4 \mathrm{~g} / \mathrm{l})$ in a 2-1 bioreactor at $70^{\circ} \mathrm{C}$. A hyperosmotic shock $\left(77^{\circ} \mathrm{C}\right.$, $\mathrm{NaCl} 3 \% \mathrm{w} / \mathrm{v}$ ) was applied at the beginning of stationery phase after $10 \mathrm{~h}$ of cultivation. The biomass was collected at different shock intervals and analysed by HPLC for MG

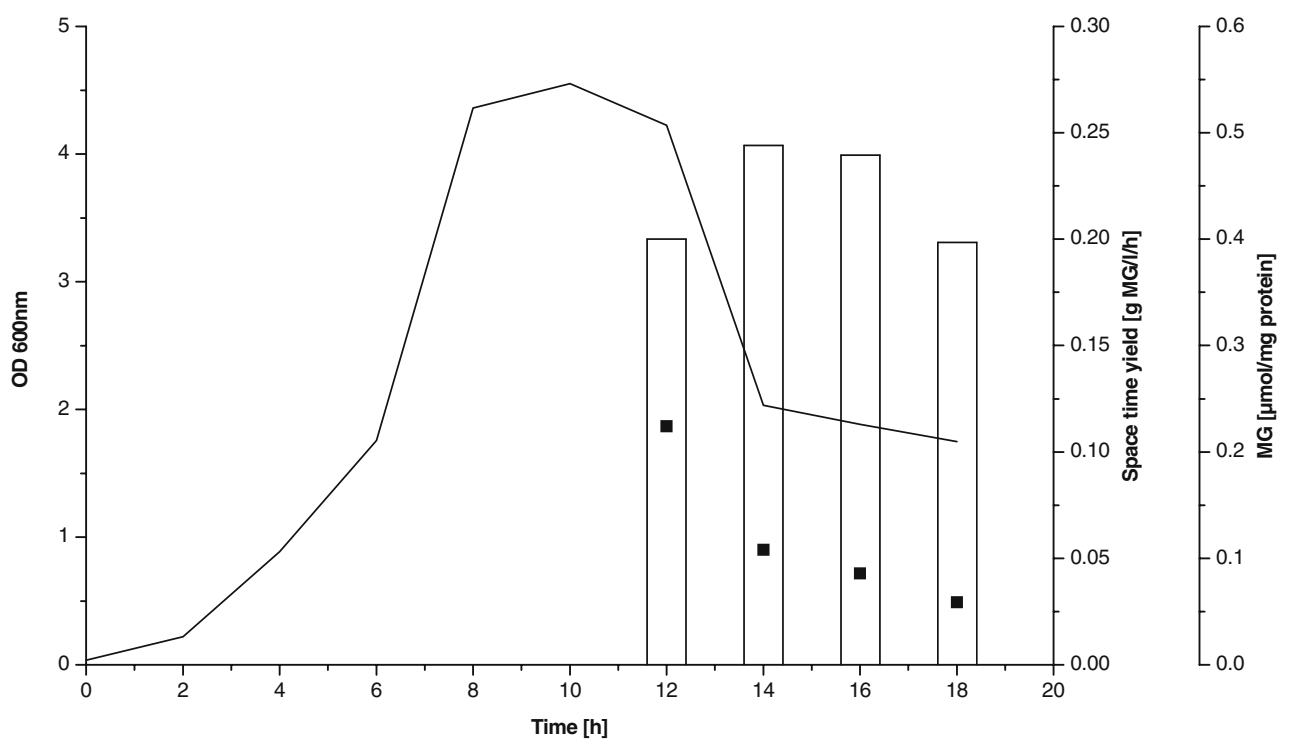




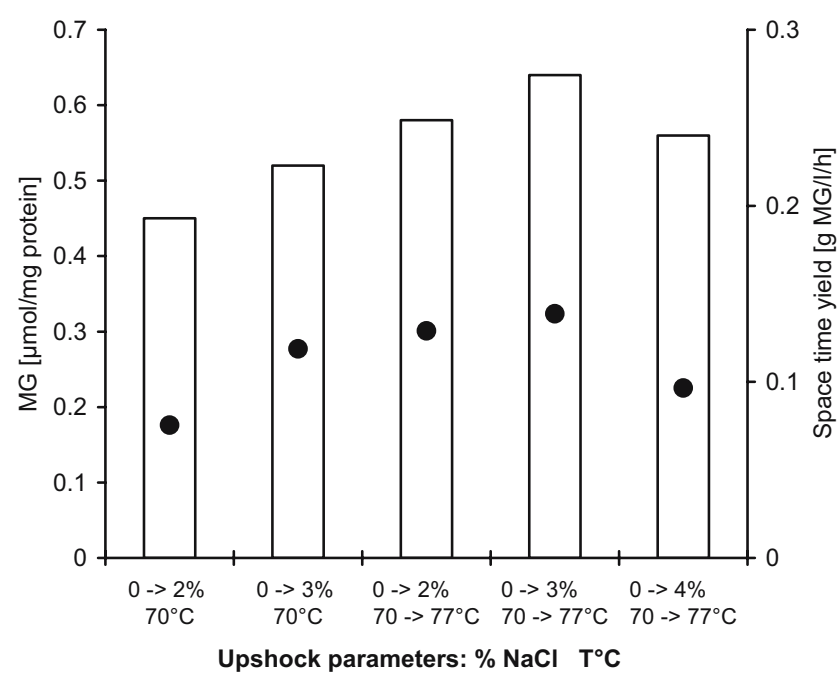

Fig. 3 Influence of different upshock parameters (salinity and/or temperature) on $\mathrm{MG}$ production in a fed-batch process using the trehalose-deficient mutant $T$. thermophilus RQ-1. Dots, production of MG (g MG $\left.~^{-1} \mathrm{~h}^{-1}\right)$; columns, intracellular concentration of MG ( $\mu \mathrm{mol}$ $\mathrm{MG} / \mathrm{mg}$ protein). The microorganism was grown on the NaCl-free complex medium with glucose feeding $(4 \mathrm{~g} / \mathrm{l})$ in a $2-1$ bioreactor at $70^{\circ} \mathrm{C}$. Upshock was applied at the beginning of stationery phase. The biomass was collected $1 \mathrm{~h}$ after the shock and analysed by HPLC for MG

of fermentation. The highest values for the intracellular content of MG $(0.64 \mu \mathrm{mol} / \mathrm{mg}$ protein $)$ and yield $(0.14 \mathrm{~g} \mathrm{MG}$ $\mathrm{l}^{-1} \mathrm{~h}^{-1}$ ) were achieved using a shift of temperature from 70

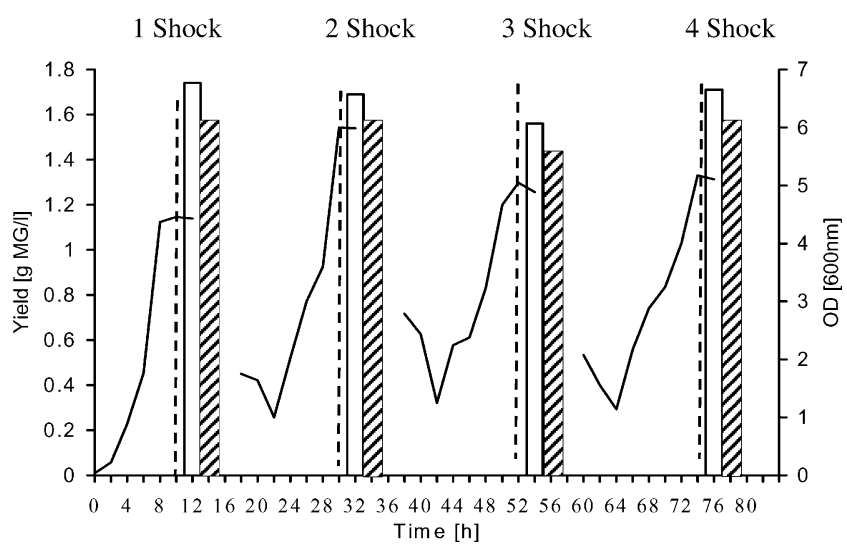

Fig. 4 Production of $\mathrm{MG}$ in a repetative fed-batch upshock fermentation by the trehalose-deficient mutant $T$. thermophilus RQ-1. Lines, microbial growth (OD $600 \mathrm{~nm})$; dash lines, points of applied hyperosmotic shock; columns, yield of MG (g MG/l), columns with bars, yield of excreted MG recovered from water (g MG/l). The microorganism was grown on the $\mathrm{NaCl}$-free complex medium with glucose feeding $(4 \mathrm{~g} / \mathrm{l})$ in a $2-1$ bioreactor at $70^{\circ} \mathrm{C}$. Upshock was applied at the beginning of stationary phase using $3 \% \mathrm{NaCl}(\mathrm{w} / \mathrm{v})$. A sample of biomass was taken $1 \mathrm{~h}$ after the shock for the HPLC analysis of MG concentration. Rest biomass was collected by centrifugation for $20 \mathrm{~min}$ at $4,000 \mathrm{rpm}$ and resuspended in equal volume of demineralized hot water $\left(70^{\circ} \mathrm{C}\right)$. The suspension was incubated at $70^{\circ} \mathrm{C}$ for $1 \mathrm{~h}$, and cells were separated by centrifugation at the same conditions, resuspended in original volume of fresh medium, and returned into the bioreactor to enable regeneration, regrowth of the cells, and resynthesis of the compatible solute. This procedure was applied four times

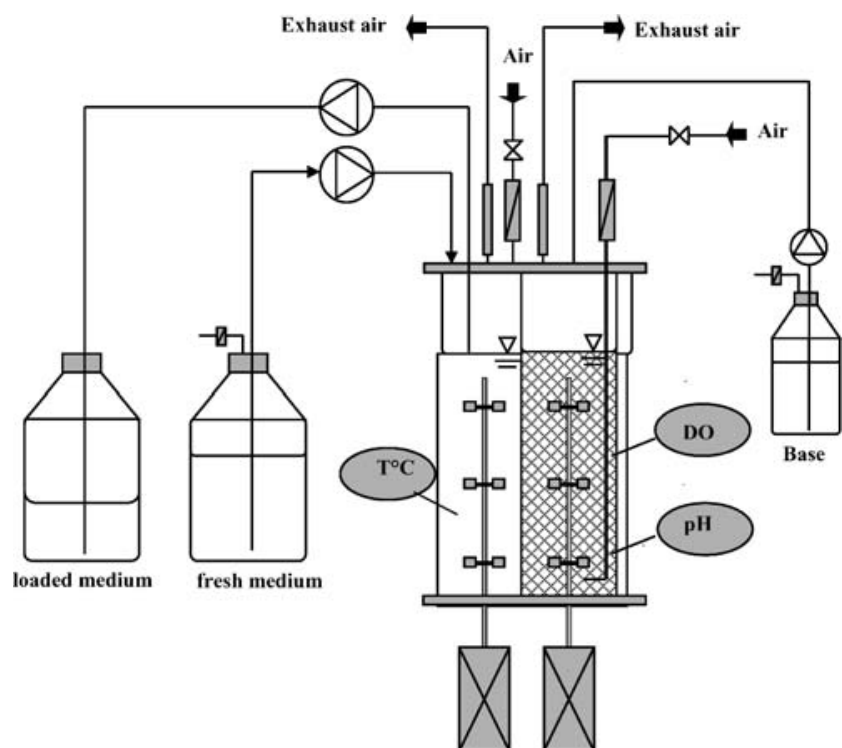

Fig. 5 A scheme of the dialysis bioreactor (Maerkl et al. 1993). DO Dissolved oxygen

to $77^{\circ} \mathrm{C}$ and $\mathrm{NaCl}$ concentration from 0 to $3 \%$ (Fig. 3). These conditions were the best tested and used in the following repetitive fed-batch and dialysis fermentations.

"Bacterial milking" and repetitive fed-batch

To achieve the excretion of MG accumulated in the cells, the hypoosmotic downshock (so-called bacterial milking) was tested (Sauer and Galinski 1998) and modified according to the physiological response of the microorganism. Bacteria suitable for the hypoosmotic downshock process should have a broad salt tolerance and should grow well in both low- and high-salt media. In addition, the halotolerant thermophile $T$. thermophilus RQ-1 lacking trehalose genes responds to hypoosmotic shock by rapid

Table 1 Comparison of MG production using different cultivation strategies

\begin{tabular}{|c|c|c|c|}
\hline Parameters & Shake flasks & Fed-batch & Dialysis \\
\hline Medium volume (1) & 0.5 & 1.6 & 0.3 \\
\hline Final $\mathrm{OD}_{600 \mathrm{~nm}}$ & 1.1 & 5.0 & 18.6 \\
\hline $\begin{array}{l}\text { MG production } \\
\text { ( } \mu \mathrm{mol} / \mathrm{mg} \text { protein })\end{array}$ & 0.26 & 0.64 & 0.62 \\
\hline $\begin{array}{l}\text { Space time yield, } \\
\left(\mathrm{g} \mathrm{MG}^{-1} \mathrm{~h}^{-1}\right)\end{array}$ & 0.01 & 0.14 & 0.29 \\
\hline Yield (g MG/l) & 0.19 & 1.74 & 4.6 \\
\hline Release MG & 100 & 90 & 90 \\
\hline
\end{tabular}

in $\mathrm{H}_{2} \mathrm{O}(\%)$

All cultivations were performed in a $\mathrm{NaCl}$-free medium at $70^{\circ} \mathrm{C}$ as described in "Materials and methods." At the early stationary phase of microbial growth, the temperature was increased up to $77^{\circ} \mathrm{C}$ and concentrated $\mathrm{NaCl}$ solution was added to a final concentration of $3 \%$ $(\mathrm{w} / \mathrm{v})$. After $1 \mathrm{~h}$ at these conditions, the concentration of $\mathrm{MG}$ and protein content were determined as described in "Materials and methods." 
release of the accumulated solute. After $1 \mathrm{~h}$ of upshock, the biomass was harvested and exposed for $1 \mathrm{~h}$ to demineralized water to achieve a hypoosmotic downshock and release of the accumulated solute into the water. This enabled harvesting of MG in the "milking" water. Near $90 \%$ of the MG accumulated in the cells was detected in the water fraction (Fig. 4). Previously, it was shown that the cells of halophiles do not lyse under hypoosmotic shock, which contributed to the purity of the excreted product (Sauer and Galinski 1998). In addition, the biomass remains physiologically active. In the second step of "bacterial milking," the biomass containing the rest (near 10\%) of compatible solute was used for a next cycle of fermentation using a fresh $\mathrm{NaCl}$-free medium. After several hours, which were needed for the regeneration process, the cells grew at $70^{\circ} \mathrm{C}$. A second upshock under the same conditions was applied allowing the cells to synthesize more solute. The process was very efficient because the cycle of temperature and $\mathrm{NaCl}$ upshock (accumulation of the solute), osmotic downshock (release of the solute), and reiterative fermentation could be repeated at least four times (Fig. 4). The application of fed-batch techniques is one of the most promising methods to increase the final cell yield and to decrease production costs, especially on an industrial scale. Fermentation of thermophilic bacteria, however, is a novel process with many aspects to be considered. Materials and sensors, e.g., electrodes, must sustain the cultivation conditions because increased diffusion rates of the constituents of the media or electrolytes at high temperatures are causing drifting and noisy signals (Sonnleitner et al. 1982). Furthermore, mass transfer is facilitated at higher temperatures because of reduced viscosity of aqueous solutions, reduced surface tension and increased diffusion of organic compounds. The opposite is true for the solubility of gases in water, for example, oxygen (Krahe et al. 1996). These results clearly demonstrated that the application of upshock fermentation and hypoosmotic downshock are one of the most promising methods to obtain high cell density and to increase yield of this compatible solute.

\section{Dialysis fermentation}

One of the major advantages of dialysis fermentation is that metabolites, which may inhibit microbial growth, can be removed from cell suspensions via diffusion, and cells benefit from additional nutrients and vitamins in the medium. Because material exchange is controlled by concentration gradients over the membrane, blocking of pores does not occur. Using this membrane bioreactor, high cell densities of prokaryotic and eukaryotic cells were obtained (Poertner and Maerkl 1998). Furthermore, a number of extremophilic microorganisms were successfully cultivated using this approach (Krahe et al. 1996). This approach results in a prolonged exponential growth phase and higher biomass yield. The dialysis fermentation was performed in the special dialysis bioreactor, consisting of two cylindrical reactors set into one another (Fig. 5; Maerkl et al. 1993). The dialysis membrane used supported the removal of low-molecular weight metabolites so far as proteins smaller than $30 \mathrm{kDa}$. Using this reactor, the strain was grown at the same conditions $\left(\mathrm{NaCl}\right.$-free medium, $\left.70^{\circ} \mathrm{C}\right)$ to an OD of 18.6, which is at least three times more compared to the data above. At this density, the cell culture was shocked using the parameters determined before as optimal for the highest MG production. The increase in temperature to $77^{\circ} \mathrm{C}$ and $\mathrm{NaCl}$ content up to $3 \% \mathrm{w} / \mathrm{v}$ in the bioreactor and in the dialysate resulted in the same level of MG accumulation in the cells $(0.62 \mu \mathrm{mol} \mathrm{MG} / \mathrm{mg}$ protein). No MG was detected in the dialysate after $1 \mathrm{~h}$ of the hyperosmotic shock. Near $90 \%$ of the accumulated intracellularly MG was realized using hypoosmotic shock with demineralized heated water. As expected, the use of the dialysis improved the production of MG significantly, reaching productivity up to $0.29 \mathrm{~g} \mathrm{MG}^{-1} \mathrm{~h}^{-1}$ (Table 1).

Acknowledgments The authors are thankful to Dana Biemann and Melanie Overbeck for skilful technical assistance. This work was funded by the European commission, fifth Frame Programme, project "Extremophiles as cell factories for the production of hypersolutes."

\section{References}

Bouveng H, Lindberg B, Wickberg B (1955) Low molecular carbohydrates in algae. Structure of the glyceric acid mannoside from red algae. Acta Chem Scand 9:807-809

Bradford MM (1976) A rapid and sensetive method for quantification of microgram quantities of protein utilizing the principle of protein-day binding. Anal Biochem 72:248-254

da Costa MS, Santos H, Galinski EA (1998) An overview of the role and diversity of compatible solutes in Bacteria and Archaea. Adv Biochem Eng Biotechnol 61:117-153

Empadinhas N, da Costa MS (2006) Diversity and biosynthesis of compatible solutes in hyper/thermophiles. Int Microbiol 9:199-206

Faria TQ, Lima JC, Bastos M, Macanita AL, Santos H (2004) Protein stabilization by osmolytes from hyperthermophiles. J Biol Chem 279:48680-48691

Fuchs C, Koester D, Wiebusch S, Mahr K, Eisbrennner G, Maerk1 H (2002) Scale-up of dialysis fermentation for high cell density cultivation of Escherichia coli. J Biotechnol 93:243-251

Gonçalves LG, Huber R, da Costa MS, Santos H (2003) A variant of the hyperthermophile Archaeoglobus fulgidus adapted to grow at high salinity. FEMS Microbiol Lett 218:239-244

Krahe M, Antranikian G, Maerkl H (1996) Fermentation of extremophilic microorganisms. FEMS Microbiol Rev 18:271-285

Lamosa P, Martins LO, da Costa MS, Santos H (1998) Effects of temperature, salinity, and medium composition on compatible solute accumulation by Thermococcus spp. Appl Environ Microbiol 64:3591-3598

Lentzen G, Schwarz T (2006) Extremolytes: natural compounds from extremophiles for versatile applications. Appl Microbiol Biotechnol 72:623-634 
Maerkl H, Zenneck C, Dubach CH, Ogbonna JC (1993) Cultivation of Escherichia coli to high cell densities in a dialysis reactor. Appl Microbiol Biotechnol 39:48-52

Martins LO, Santos H (1995) Accumulation of mannosylglycerate and di-myo-inositol-phosphate by Pyrococcus furiosus in response to salinity and temperature. Appl Environ Microbiol 61: 3299-3303

Martins LO, Huber R, Huber H, Stetter KO, da Costa MS, Santos H (1997) Organic solutes in hyperthermophilic Archaea. Appl Environ Microbiol 63:896-902

Neves C, da Costa MS, Santos H (2005) Compatible solutes of the hyperthermophile Palaeococcus ferrophilus: osmoadaptation and thermoadaptation in the order thermococcales. Appl Environ Microbiol 71:8091-8098

Nunes OC, Manaia CM, da Costa MS, Santos H (1995) Compatible solutes in the thermophilic Bacteria Rhodothermus marinus and Thermus thermophilus. Appl Environ Microbiol 61:2351-2357

Poertner R, Maerkl H (1998) Dialysis cultures. Appl Microbiol Biotechnol 50:403-414
Reed RH, Richardson DL, Warr SRC, Hensel WDP (1992) Carbohydrate accumulation and osmotic stress in Cyanobacteria. J Gen Microbiol 130:1-4

Sauer T, Galinski EA (1998) Bacterial milking: a novel bioprocess for production of compatible solutes. Biotechnol Bioeng 57:307-313

Silva Z, Borges N, Martins LO, Wait R, da Costa MS, Santos H (1999) Combined effect of the growth temperature and salinity of the medium on the accumulation of compatible solutes by Rhodothermus marinus and Rhodothermus obamensis. Extremophiles 3:163-172

Silva Z, Alarico S, Nobre A, Horlacher R, Marugg J, Boos W, Mingote AI, da Costa MS (2003) Osmotic adaptation of Thermus thermophilus RQ-1: lesson from a mutant deficient in synthesis of trehalose. J Bacteriol 185:5943-5952

Sonnleitner B (1983) Biotechnology of thermophilic bacteria-growth, products and application. Adv Biochem Eng Biotechnol 28: 69-138

Sonnleitner B, Cometta S, Fiechter A (1982) Growth kinetics of Thermus thermophilus. Appl Microbiol Biotechnol 15:75-82 